Int. J. Electrochem. Sci., 11 (2016) $7785-7800$

International Journal of

ELECTROCHEMICAL

SCIENCE

www.electrochemsci.org

\title{
Inhibition Effects of a Quaternary Ammonium-Based Ionic Liquid on Steel in Acid Solution: Electrochemical and Surface Analyses
}

Paulina Arellanes-Lozada ${ }^{1}$, Octavio Olivares-Xomett ${ }^{2,}$, Natalya V. Likhanova ${ }^{3}$, Elsa M. ArceEstrada ${ }^{1}$, Irina V. Lijanova ${ }^{5}$, Luis Lartundo-Rojas ${ }^{4}$ and Ma. de Consuelo Mendoza-Herrera ${ }^{2}$.

${ }^{1}$ Instituto Politécnico Nacional, ESIQIE, Departamento de Metalurgia y Materiales, UPALM, Ed. 7, 07738, México, D.F., México.

${ }^{2}$ Benemérita Universidad Autónoma de Puebla, Facultad de Ingeniería Química, Av. San Claudio, Ciudad Universitaria. Col. San Manuel, 72570, Puebla, Pue. México.

${ }^{3}$ Instituto Mexicano del Petróleo, Gerencia de Ingeniería de Recuperación Adicional, Eje Central Lázaro Cárdenas No. 152, Col. San Bartolo Atepehuacán, 07730, México, D.F., México.

${ }^{4}$ Instituto Politécnico Nacional, Centro de Nanociencias y Micro y Nanotecnologías, Luis Enrique Erro s/n, Zacatenco, 07738, México, D.F., México.

${ }^{5}$ Instituto Politécnico Nacional, CIITEC, Cerrada Cecati S/N, Colonia Santa Catarina de Azcapotzalco, 02250, México, D.F., México.

*E-mail: oxoctavio@yahoo.com.mx

doi: $10.20964 / 2016.09 .55$

Received: 3 June 2016 / Accepted: 15 July 2016 / Published: 7 August 2016

The present work reports the performance of N-dimethyl-N-di(cocoalkyl) ammonium methyl sulfate (DCA), as a corrosion inhibitor of API-X52 carbon steel exposed to a $1 \mathrm{M} \mathrm{HCl}$ solution. The EIS technique was used to assess the inhibition efficiency. Surface analyses were performed by XPS and GIXRD. The addition of DCA to the corrosive solution promoted the formation of an interfacial protective layer, which can include corrosion products such as $\mathrm{FeO}(\mathrm{OH})$ and $\mathrm{FeCl}_{2} \cdot n \mathrm{H}_{2} \mathrm{O}$. The long term stability of DCA was ascertained by the ICP-OES technique. The inhibition efficiency subsequent to 1 month of solution immersion was $97 \%$.

Keywords: Ionic-liquid; Acid media; EIS; XPS; Corrosion inhibitor.

FULL TEXT 
(C) 2016 The Authors. Published by ESG (www.electrochemsci.org). This article is an open access article distributed under the terms and conditions of the Creative Commons Attribution license (http://creativecommons.org/licenses/by/4.0/). 